\title{
PENGARUH KEPUASAN PELANGGAN, KEPERCAYAAN PELANGGAN DAN SALURAN DISTRIBUSI TERHADAP KEPUTUSAN PEMBELIAN BAJA PADA PT SUMINSURYAMESINDOLESTARI
}

\author{
Demak Claudia Yosephine Simanjuntak ${ }^{1}$ \\ Vicdy Anche Salimi ${ }^{2}$ \\ Vincent Louis ${ }^{3}$ \\ Toni Johanes ${ }^{4}$ \\ Program Studi Manajemen, Universitas Prima Indonesia, Medan \\ email : claudiayoseph8@gmail.com
}

\begin{abstract}
ABSTRAK
Kepuasan pelanggan berperan penting dalam upaya peningkatkan keputusan pembelian. Tujuan penelitian adalah menguji dan menganalisis pengaruh Kepuasan Pelanggan, Kepercayaan Pelanggan dan Saluran Distribusi terhadap Keputusan Pembelian Baja pada PT Suminsurya Mesindolestari Medan. Penelitian ini menggunakan metode deskriptif kuantitatif dengan populasi dalam penelitian ini berjumlah 204 pelanggan PT Suminsurya Mesindolestari Medan dan sampel dalam penelitian ini adalah sebanyak 134 pelanggan, teknik sampling yang digunakan yaitu sampling random sampling Hasil penelitian menunjukkan bahwa Kepuasan Pelanggan, Kepercayaan Pelanggan dan Saluran Distribusi berpengaruh positif dan signifikan terhadap Keputusan Pembelian Baja pada PT Suminsurya Mesindolestari Medan. Peningkatan ketiga variabel tersebut baik secara parsial maupun bersama-sama dapat meningkatkan keputusan pembelian secara maksimal. Maka disarankan agar perusahaan dapat meningkatkan dan memperbaiki kedua variabel tersebut di dalam perusahaan.

Kata kunci : kepuasan pelanggan, kepercayaan pelanggan, saluran distribusi, keputusan pembelian
\end{abstract}

\begin{abstract}
Customer satisfaction plays an important role in efforts to improve purchasing decisions. The research objective is to test and analyze the influence of Customer Satisfaction, Customer Trust and Distribution Channels on Steel Purchasing Decisions at PT Suminsurya Mesindolestari Medan. This research uses descriptive quantitative method with the population in this study amounting to 204 customers of PT Suminsurya Mesindolestari Medan and the samples in this study were 134 customers, the sampling technique used is random sampling and significant towards the Steel Purchasing Decision at PT Suminsurya Mesindolestari Medan. Increasing these three variables both partially and together can increase purchasing decisions optimally. So it is suggested that the company can improve and improve both variables within the company.
\end{abstract}

Keywords: customer satisfaction, customer trust, distribution channels, purchasing decision 


\section{PENDAHULUAN}

Keberhasilan perusahaan dalam memasarkan produk sangat tergantung pada penerapan strategi pemasaran yang tepat melalui kiat-kiat dan strategi pemasaran yang dilakukan. Berbagai macam keputusan PT. Suminsurya Mesindolestari Medan mengenai aktivitas kehidupan dilakukan setiap hari oleh setiap konsumen tanpa menyadari bahwa mereka telah mengambil keputusan. Dewasa ini semakin diyakini bahwa kunci utama untuk memenangkan persaingan adalah memberikan nilai dan kepuasan kepada pelanggan, kepercayaan dan saluran distribusi terhadap keputusan pembelian yang efektif.

Kepuasan menurut Tjiptono (2015) berasal dari bahasa latin yaitu "satis" yang berarti cukup baik atau memadai dan "facio" berarti melakukan atau membuat. Kepuasan pelanggan merupakan evaluasi terhadap surprise yang inheren atau melekat pada pemerolehan produk dan/atau pengalaman konsumsi. Churchill \& Suprenant, merumuskan kepuasan pelanggan sebagai hasil 2 pembelian dan pemakaian yang didapatkan dari perbandingan antara reward dan biasa pembelian dengan konsekuensi yang diantisipasi sebelumnya. Day mendefinisikan kepuasan pelanggan sebagai penilaian evaluatif purnabeli spesifik

Menurut Kotler \& Keller (2009) kepuasan pelanggan adalah perasaan senang atau kecewa seseorang yang muncul setelah membandingkan antara persepsi atau kesannya terhadap kinerja berada di bawah harapan, pelanggan tidak puas. Tapi, jika kinerja melebihi harapan, pelanggan amat puas dan senang. Jika kinerja yang dirasakan di bawah harapan, pelanggan tersebut akan merasa dikecewakan, jika kinerja memenuhi harapan pelanggan, pelanggan akan merasa puas, sedangkan jika kinerja melebihi harapan maka pelanggan akan merasa sangat puas. Kepuasan ini tentu akan dapat dirasakan setelah pelanggan yang bersangkutan mengkonsumsi produk tersebut.

Kepuasan pelanggan berperan penting dalam upaya peningkatkan keputusan pembelian. Persaingan yang semakin ketat, dimana banyak produsen yang terlibat dalam pemenuhan kebutuhan dan keinginan konsumen, menyebabkan setiap perusahaan harus menempatkan orientasi pada kepuasan pelanggan sebagaitukuan utama. Hal ini tercermin dari semakin banyaknya perusahaan yang menyertakan komitmen terhadap kepuasan pelanggan PT. Suminsurya Mesindolestari Medan dalam pernyataan iklan maupun public relations release.

Menurut Kotler dan Keller (2017) kepercayaan adalah kesediaan perusahaan untuk bergantung pada mitra bisnis. Kepercayaan tergantung pada beberapa faktor antar pribadi dan antar organisasi seperti kompetensi, integritas, kejujuran dan kebaikan hati. Membangun kepercayaan bisa menjadi hal yang sulit dalam situasi online, perusahaan menerapkan peraturan ketat kepada mitra bisnis online mereka dibanding mitra lainnya. Pembeli bisnis khawatir bahwa mereka tidak akan mendapatkan produk atau jasa dengan kualitas yang tepat dan dihantarkan ke tempat yang tepat pada waktu yang tepat, begitupun sebaliknya.

Menurut Andromeda (2015) kepercayaan konsumen terhadap website online shopping terletak pada popularitas website online shopping itu sendiri, semakin bagus suatu website, konsumen akan lebih yakin dan percaya terhadap reliabilitas website tersebut. Aribowo dan Nugroho (2013) berpendapat bahwa kepercayaan 
dari pihak tertentu terhadap pihak lain yang bersangkutan dalam melakukan hubungan transaksi didasarkan pada suatu keyakinan bahwa orang yang dipercayainya akan memenuhi segala kewajibannya secara baik sesuai dengan yang diharapkan. Menurut Firdayanti (2012) kepercayaan konsumen merupakan persepsi dari sudut pandang konsumen akan keandalan penjual dalam pengalaman dan terpenuhinya harapan dan kepuasan konsumen.

Kepercayaan pelanggan PT. Suminsurya Mesindolestari Medan diperlukan agar semua pengetahuan yang dimiliki oleh pelanggan dan semua kesimpulan yang dibuat pelanggan tentang objek, atribut dan manfaatnya. Objek dapat berupa produk, orang, perusahaan dan segala sesuatu dimana seseorang memiliki kepercayaan dan sikap. Kepercayaan secara umum dipandang sebagai unsur mendasar bagi keberhasilan relationship. Tanpa adanya kepercayaan, suatu relationship tidak akan bertahan dalam jangka waktu yang panjang.

Menurut Kotler \& Keller (2009) Saluran distribusi adalah sekelompok organisasi yang saling bergantung dan terlibat dalam proses pembuatan produk atau jasa yang disediakan untuk digunakan atau dikonsumsi. Sedangkan menurut Swastha \& Handoko (2000) Saluran distribusi merupakan suatu struktur organisasi dalam perusahaan dan luar perusahaan yang terdiri atas agen, dealer, pedagang besar, dan pengecer, melalui sebuah komoditi, produk, atau jasa dipasarkan.

Saluran distribusi mempunyai manfaat bagi produsen PT. Suminsurya Mesindolestari Medan yaitu sebagai berikut membantu prosuen dalam memperlancar aliran barang dan jasa kepada konsumen, membantu produsesn dalam bidang keuangan sebagai salah satu sumber keuangan perusahaan, menciptakan efisiensi karena pengeluaran untuk penyaluran barang kepad akonsumen sudah ditangani perantaran dan patokan dalam menentukan harga barang dan jasa serta diskusi yang diberikan

PT. Suminsurya Mesindolestari Medan adalah sebuah perusahaan yang bergerak di bidang penjualan baja dan mesin. PT. Suminsurya Mesindolestari Medan berlokasi di jalan Irian Barat No. 320 Kongsi VI Kec Percut Sei Tuan Medan. Wilayah penjualan adalah Sumatera Utara dan lebih banyak di Kota Medan serta di daerah-daerah lain seperti Brastagi, Aceh dan lain-lain. PT Suminsurya Mesindolestari Medan merupakan sebuah perusahaan yang bergerak di bidang penjualan berbagai jenis dan ukuran baja.

Tabel 1. menunjukkan bahwa tidak tercapainya target penjualan setiap bulannya. Realisasi tertinggi terjadi pada bulan Februari 2018 sebesar Rp 7.456.140.000 atau 86,5\% yang disebabkan adanya dorongan kepada penjual dengan paket pembelian sehingga banyak pelanggan tertarik. Realisasi yang terendah terjadi pada bulan Juli 2018 sebesar Rp 5.056.845.000 atau 59,49\%. Hal ini dikarenakan jumlah produk yang sedikit dan adanya perubahan sistem pembayaran yang diharuskan melewati transfer dan tidak bisa pembayaran tunai.

Keputusan pembelian merupakan serangkaian proses yang berawal dari konsumen mengenal masalahnya, mencari informasi tentang produk atau merek tertentu dan mengevaluasi produk atau merek tersebut seberapa baik masingmasing alternatif tersebut dapat memecahkan masalahnya, yang kemudian 
serangkaian proses tersebut mengarah kepada keputusan pembelian (Tjiptono, 2015).

Tabel 1.

Data Target dan Realisasi Penjualan PT. Suminsurya Mesindolestari Medan Januari s/d Desember 2019

\begin{tabular}{cccccc}
\hline Bulan & $\begin{array}{c}\text { Target } \\
\text { Penjualan } \\
(\mathbf{R P})\end{array}$ & $\begin{array}{c}\text { Realisasi } \\
\text { Penjualan } \\
(\mathbf{R P})\end{array}$ & $\begin{array}{c}\text { Selisih } \\
(\mathbf{R P})\end{array}$ & $\begin{array}{c}\text { Selisih } \\
(\boldsymbol{\%})\end{array}$ & $\begin{array}{c}\text { Capai } \\
(\boldsymbol{\%})\end{array}$ \\
\hline Januari & $8,500,000,000$ & $6,545,000,000$ & $1,955,000,000$ & $23,00 \%$ & $77,00 \%$ \\
Februari & $8,500,000,000$ & $7,352,500,000$ & $1,147,500,000$ & $13,50 \%$ & $86,50 \%$ \\
Maret & $8,500,000,000$ & $7,024,180,000$ & $1,475,820,000$ & $17,36 \%$ & $82,64 \%$ \\
April & $8,500,000,000$ & $6,889,250,000$ & $1,610,750,000$ & $18,95 \%$ & $81,05 \%$ \\
Mei & $8,500,000,000$ & $5,356,700,000$ & $3,143,300,000$ & $36,98 \%$ & $63,02 \%$ \\
Juni & $8,500,000,000$ & $5,225,800,000$ & $3,274,200,000$ & $38,52 \%$ & $61,48 \%$ \\
Juli & $8,500,000,000$ & $5,056,845,000$ & $3,443,155,000$ & $40,51 \%$ & $59,49 \%$ \\
Agustus & $8,500,000,000$ & $6,774,584,000$ & $1,725,416,000$ & $20,30 \%$ & $79,70 \%$ \\
September & $8,500,000,000$ & $5,183,412,000$ & $3,316,588,000$ & $39,02 \%$ & $60,98 \%$ \\
Oktober & $8,500,000,000$ & $7,144,963,000$ & $1,355,037,000$ & $15,95 \%$ & $84,05 \%$ \\
November & $8,500,000,000$ & $6,066,640,000$ & $2,433,360,000$ & $28,63 \%$ & $71,37 \%$ \\
Desember & $8,500,000,000$ & $5,306,576,000$ & $3,193,424,000$ & $37,57 \%$ & $62,43 \%$ \\
\hline
\end{tabular}

Sumber : PT. Suminsurya Mesindolestari Medan, (2020)

Menurut Kotler \& Keller (2009) "Keputusan pembelian adalah Suatu tahap dimana konsumen telah memiliki pilihan dan siap untuk melakukan pembelian atau pertukaran antara uang dan janji untuk membayar dengan hak kepemilikan atau penggunaan suatu barang atau jasa". Kotler \& Keller (2009) juga menjelaskan yang dimaksud dengan keputusan pembelian adalah suatu proses penyelesaian masalah yang terdiri dari menganalisa atau pengenalan kebutuhan dan keinginan hingga perilaku setelah pembelian. Menurut Peter \& Olson (2013) keputusan pembelian adalah proses mengkombinasikan pengetahuan untuk mengevaluasi dua atau lebih perilaku alternatif dan memilih salah satu diantaranya. Keputusan pembelian menurut Schiffman \& Kanuk (2007) adalah pemilihan suatu tindakan dari dua pilihan alternatif atau lebih.

Menurut Setiadi (2010) perilaku membeli mengandung makna yakni kegiatan-kegiatan individu secara langsung terlibat dalam pertukaran uang dengan barang dan jasa serta dalam proses pengambilan keputusan yang menentukan kegiatan tersebut. Keputusan konsumen untuk membeli suatu produk selalu melibatkan aktivitas secara fisik (berupa kegiatan langsung konsumen melalui tahapan-tahapan proses pengambilan keputusan pembelian) dan aktivitas secara mental (yakni saat konsumen menilai produk sesuai dengan kriteria tertentu yang ditetapkan oleh individu).

Keputusan pembelian merupakan pemikiran dimana individu mengevaluasi berbagai pilihan dan memutuskan pilihan pada suatu produk dari sekian banyak pilihan. Menurut Kotler et al. (2016) keputusan pembelian adalah tahap dalam proses pengambilan keputusan pembeli di mana konsumen benar-benar membeli. Menurut Schiffman \& Kanuk (2007) keputusan pembelian didefinisikan sebagai 
sebuah pilihan dari dua tahu lebih alternatif pilihan. Menurut Tjiptono (2015) keputusan pembelian adalah sebuah proses dimana konsumen mengenal masalahnya, mencari informasi mengenai produk atau merek tertentu dan mengevaluasi secara baik masing-masing alternatif tersebut dapat memecahkan masalahnya, yang kemudian mengarah kepada keputusan pembelian.

Dari pengertian tersebut dapat disimpulkan keputusan pembelian merupakan sebuah proses pengambilan keputusan yang diawali dengan pengenalan masalah kemudian mengevaluasinya dan memutuskan produk yang paling sesuai dengan kebutuhan.

Proses pengambilan keputusan diawali oleh adanya kebutuhan yang berusaha untuk dipenuhi. Pemenuhan kebutuhan ini terkait dengan beberapa alternatif sehingga perlu di lakukan evaluasi yang bertujuan untuk memperoleh alternatif terbaik dari persepsi konsumen. Pada perusahaan ini menurunnya keputusan pembelian baja yang dilakukan oleh pelanggan. Penurunan Keputusan Pembelian ini tercemin dari penjualan mengalami penurunan baja dari bulan Januari sampai bulan Desember 2018.

Memahami keputusan pembelian dapat memberikan gambaran kepada para pemasar dalam pembuatan produk, penyesuaian harga produk, mutu produk, kemasan dan sebagainya agar dalam penjualan produknya tidak menimbulkan kekecawaan pada pemasar tersebut.

Kepuasan pelanggan berperan penting dalam keputusan pembelian yanag dilakukan oleh pelanggan. Pada perusahaan ini terjadinya peningkatan keluhan pelanggan kepada perusahaan. Banyaknya keluhan ini berupa mengenai pelayanan yang belum memuaskan yaitu dalam kecepatan dalam menagani keluhan dari para pelangga, kepuasan terhadap harga yang sering fluktuasi dan sebagainya. Berikut adalah Tabel 2. keluhan pelanggan yang mencerminkan kekecewaaan pelanggan kepada perusahaan.

Tabel 2. menunjukkan bahwa tingginya keluhan pelanggan kepada perusahaan hal ini menunjukkan betapa tidak berkualitasnya pelayanan yang diberikan yang menciptakan kekecewaaan pelanggan yang tidak singgap dalam memberikan pelayanan dan ketidaksesuaian pesanan. Hal ini berdampak pada keputusan pembelian yang mengalami penurunan terbukti dari banyaknya pelanggan yang lebih memilih membeli pada perusahaan lainnya yang sejenis yang lebih memuaskan.

Banyaknya pelanggan yang kurang mempercayai staf perusahaan PT Suminsurya Mesindolestari Medan. Hal ini menyebabkan jumlah pelanggan yang mengalami penurunan. Penyebab ketidakpercayaan dari pelanggan PT Suminsurya Mesindolestari Medan adalah seringnya infromasi yang diberikan tidak reliabel baik dari segi informasi produk maupun harga produk baja. Hal ini seringnya menimbulkan kekecewaaan yang berdampak banyak pelanggan PT Suminsurya Mesindolestari Medan berahli ke perusahaan lain.

Tabel 3. menunjukkan bahwa terjadinya penurunan pelanggan pada perusahaan yang diakibatkan ketidakreliabel para staf perusahaan. Besarnya kepercayaan konsumen terhadap suatu perusahaan dan produk atau jasa yang dijual berkaitan dengan besarnya kepercayaan mereka terhadap sistem pembayaran yang digunakan perusahaan yang sungguh mengecewakan para 
pelanggan serta reputasi yang serign tidak tanggap dan reliabel dalam melayani menjadi faktor pemicu ketidakpercayaan pelanggan.

Tabel 2.

Data Keluhan Pelanggan PT. Suminsurya Mesindolestari Medan Januari s/d Desember 2018

\begin{tabular}{ccll}
\hline Bulan & $\begin{array}{c}\text { Jumlah } \\
\text { Keluhan }\end{array}$ & \multicolumn{1}{c}{ Penyebab } \\
\hline Januari & 6 & 1. Ketidakpuasan dengan pengantaran baja yang lambat / \\
Februari & 9 & bermasalah & 2. Ketidakpuasan dengan pengantran orderan tidak sesuai \\
Maret & 5 & pesanan \\
April & 4 & 3. Ketidakpuasan dengan Komunikasi yang kurang baik antara \\
Mei & 3 & customer dan supplier \\
Juni & 4 & 4. Ketidakpuasan dalam penetapan harga besi yang terkadang \\
Juli & 6 & berubah-berubah \\
Agustus & 4 & 5. Ketidakpuasan dengan tidak antar full dan tidak ada kabar \\
September & 5 & 7. Proses retur yang tidak cepat \\
Oktober & 6 & 8. Ketidaktanggapan dalam melayani \\
November & 8 & 7 &
\end{tabular}

Sumber : PT. Suminsurya Mesindolestari Medan, (2020)

Tabel 3.

Data Keluhan Pelanggan Baja PT. Suminsurya Mesindolestari Medan Januari s/d Desember 2018

\begin{tabular}{|c|c|c|}
\hline Bulan & Keluhan & Keterangan \\
\hline Januari & 4 & 1. Ketidaktanggapan terhadap keluhan pelanggan seperti kurang \\
\hline Februari & 3 & cepat dan tepat \\
\hline Maret & 2 & \\
\hline April & 4 & 2. Informasi yang diberikan tidak valid \\
\hline Mei & 5 & \\
\hline Juni & 6 & 3. Harga yang tidak sesuai kesepakatan Karena berbeda dengan \\
\hline Juli & 3 & \\
\hline Agustus & 2 & 4. Pelayanan yang buruk disebabkan karena ketidaksopanan \\
\hline September & 4 & dalam melayani pelanggan ketika ingin melakukan retur produk \\
\hline Oktober & 3 & \\
\hline November & 6 & 5. Sulit menghubungi staf marketing yang bersangkutan \\
\hline \multirow[t]{3}{*}{ Desember } & 7 & \\
\hline & & 6. Pelayanan yang diberikan lambat seperti \\
\hline & & $\begin{array}{l}\text { 7. Seringnya baja yang diterima tidak sesuai dengan pesanan } \\
\text { pelanggan }\end{array}$ \\
\hline
\end{tabular}

Sumber : PT. Suminsurya Mesindolestari Medan, (2020)

Saluran distribusi berperang aktif dalam peningkatan maupun penurunan keputusan pembelian. Pada perusahaan ini saluran distribusi yang belum efektif menimbulkan keluhan berupa seringnya produk baja yang di pesan tidak sesuai jadwal pengantaran yang telah disepaakati, jenis dan ukuran yang di pesan sering mengalami kesalahan, beberapa produk baja seringnya kosong sehingga belum dapat memenuhi keinginan pelanggan dengan cepat dan tepat. 
Tabel 4. Menunjukkan bahwa tingginya keluhan mengenai kurang efektif saluran distribusi yang dimiliki oleh perusahaan sehingga menimbulkan kekecewaan pelanggan. Keluhan tertinggi terjadi pada bulan Desember. Dimana keterangan keluhan berupakan pengiriman tidak tepat waktu, ketidaksesuaian jumlah produk, dan jenis yang diinginkan pelanggan tidak sesuai dengan pesanan. Hal ini diakibatkan cakupan pasar yang cukup jauh dan komunikasi yang kurang dilakukan oleh pihak perusahaan kepada pelanggan.

Tabel 4.

Data Saluran Distribusi PT. Suminsurya Mesindolestari Medan Januari s/d Desember 2018

\begin{tabular}{lccl}
\hline \multicolumn{1}{c}{ Bulan } & Jumlah Keluhan & \multicolumn{2}{c}{ Deskripsi Permasalahan } \\
\hline Januari & 2 & Pelanggan sudah memesan tetapi belum \\
Februari & 1 & diantar sehingga pelanggan membatalkan \\
Maret & 3 & pesanan karena telah memesan pada \\
April & 4 & perusahaan lain \\
Mei & 2 & Barang yang dikirim melalui jasa pengiriman \\
Juni & 3 & barang tidak sampai sekaligus, sedangkan \\
Juli & 2 & faktur digabung \\
Agustus & 1 & Kurangnya mobil untuk mendistribusikan \\
September & 1 & karena sedang dalam masa perbaikan \\
Oktober & 3 & - Mobil sudah kurang layak pakai \\
November & 5 & \\
Desember & 4 &
\end{tabular}

Dari permasalahan diatas peneliti merasa perlu melakukan penelitian sehingga peneliti mengambil judul : "Pengaruh Kepuasan Pelanggan, Kepercayaan Pelanggan dan Saluran Distribusi terhadap Keputusan Pembelian Baja pada PT Suminsurya Mesindolestari Medan."

Kerangka Konseptual dapat digambarkan pada keranga konseptual di bawah ini.

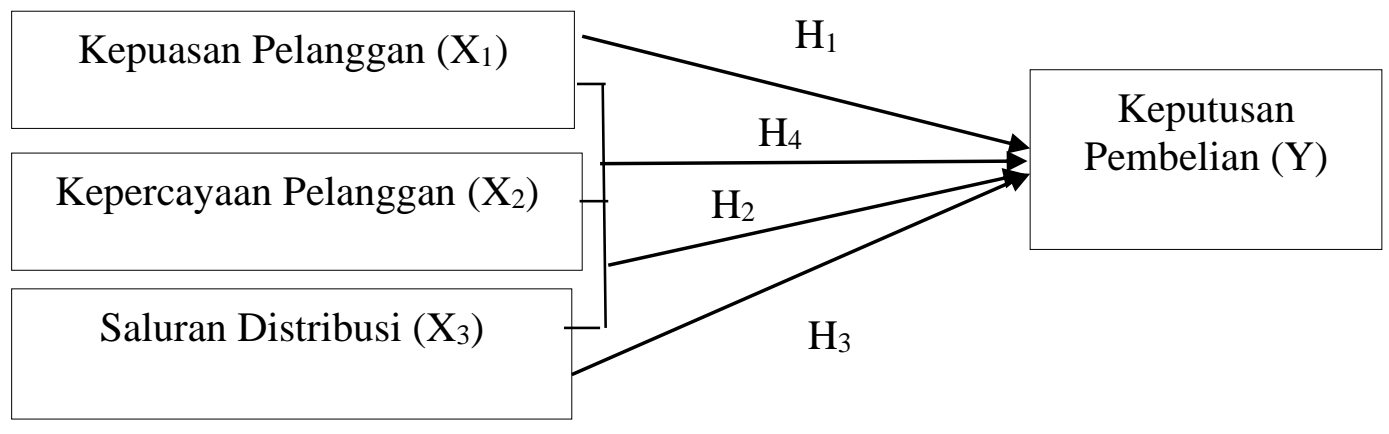

\section{Gambar 1. Kerangka Konseptual}

Menurut Malau (2017) "Tingkah laku tentang keputusan pembelian individu, kelompok atau organisasi dan proses merek digunakan untuk memilih, produk dengan cara pencapaian kepuasan pelanggan dalam mengkonsumsi suatu produk." 
Menurut Limakrisna \& Susilo (2012) "Kepercayaan merupakan alat yang sangat penting dalam pemasaran yang menjadi salah satu faktor yang dapat mempengaruhi keputusan pembelian pelanggan dalam suatu produk di dalam sektor publik."

Menurut Nitisusastro (2012) "semakin banyak perusahaan menggunakan perusahaan saluran distribusi, pada dasarnya semakin memudahkan para konsumen untuk melakukan pembelian dan diterima tepat pada waktu barang itu dibutuhkan."

Menurut Sugiyono (2017), hipotesis merupakan jawaban sementara terhadap rumusan masalah penelitian, dimana rumusan masalah penelitian telah dinyatakan dalam kalimat pertanyaan. Dari kerangka konseptual diatas dapat ditarik hipotesis penelitian yaitu:

$\mathrm{H}_{1}$ : Kepuasan Pelanggan berpengaruh secara parsial terhadap Keputusan Pembelian Baja pada PT Suminsurya Mesindolestari Medan.

$\mathrm{H}_{2}$ : Kepercayaan Pelanggan berpengaruh secara parsial terhadap Keputusan Pembelian Baja pada PT Suminsurya Mesindolestari Medan.

$\mathrm{H}_{3}$ : Saluran Distribusi berpengaruh secara parsial terhadap Keputusan Pembelian Baja pada PT Suminsurya Mesindolestari Medan.

$\mathrm{H}_{4}$ : Kepuasan Pelanggan, Kepercayaan Pelanggan dan Saluran Distribusi berpengaruh secara simultan terhadap Keputusan Pembelian Baja pada PT Suminsurya Mesindolestari Medan.

\section{METODE PENELITIAN}

Penelitian ini dilakukan pada PT Suminsurya Mesindolestari Medan yang beralamat di Jalan Irian Barat No. 320 Kongsi VI kec Percut Sei Tuan Medan. Waktu penelitian proposal penelitian dimulai sejak bulan April sampai pada bulan Desember.

Pendekatan penelitian ini berdasarkan pendekatan kuantitatif. Menurut Sangadji \& Sopiah (2013) menjelaskan bahwa penelitian kuantitatif adalah penelitian yang lebih berdasarkan pada data yang dapat dihitung untuk menghasilkan suatu penafsiran. Dalam penelitian ini, peneliti menggunakan metode penelitian deskriptif kuantitatif. Menurut Arikunto (2014) penelitian deskriptif adalah penelitian yang menggunakan penelitian korelasi yang bertujuan untuk mencari pengaruh antara variabel yang satu dengan variabel lainnya.

Menurut Sugiyono (2017), "Populasi adalah wilayah generalisasi yang terdiri atas obyek atau subyek yang mempunyai kualitas dan karakteristik tertentu yang ditetapkan oleh peneliti untuk dipelajari dan kemudian ditarik kesimpulannya." Populasi dalam penelitian ini berjumlah 204 pelanggan. Menurut Sugiyono (2017) "Sampel adalah bagian dari jumlah dan karakteristik yang dimiliki oleh populasi.'Teknik sampling yang digunakan adalah sampling random sampling. Menentukan jumlah sampel, dapat menggunakan rumus Slovin yaitu : 


$$
\begin{aligned}
\mathrm{N} & =\frac{\mathrm{N}}{1+\mathrm{Ne}^{2}} \\
& =\frac{203}{1+203 \times 0.05^{2}} \\
& =134
\end{aligned}
$$

Keterangan :

n Ukuran Sampel

N Populasi

e Prosentasi kelonggaran ketidakterikatan karena kesalahan pengambilan sampel yang masih diinginkan

Penelitian ini adalah sebanyak 134 pelanggan dan 30 pelanggan diambil diluar dari sampel 134 pelanggan.

Tabel 5.

Jadwal Penelitian

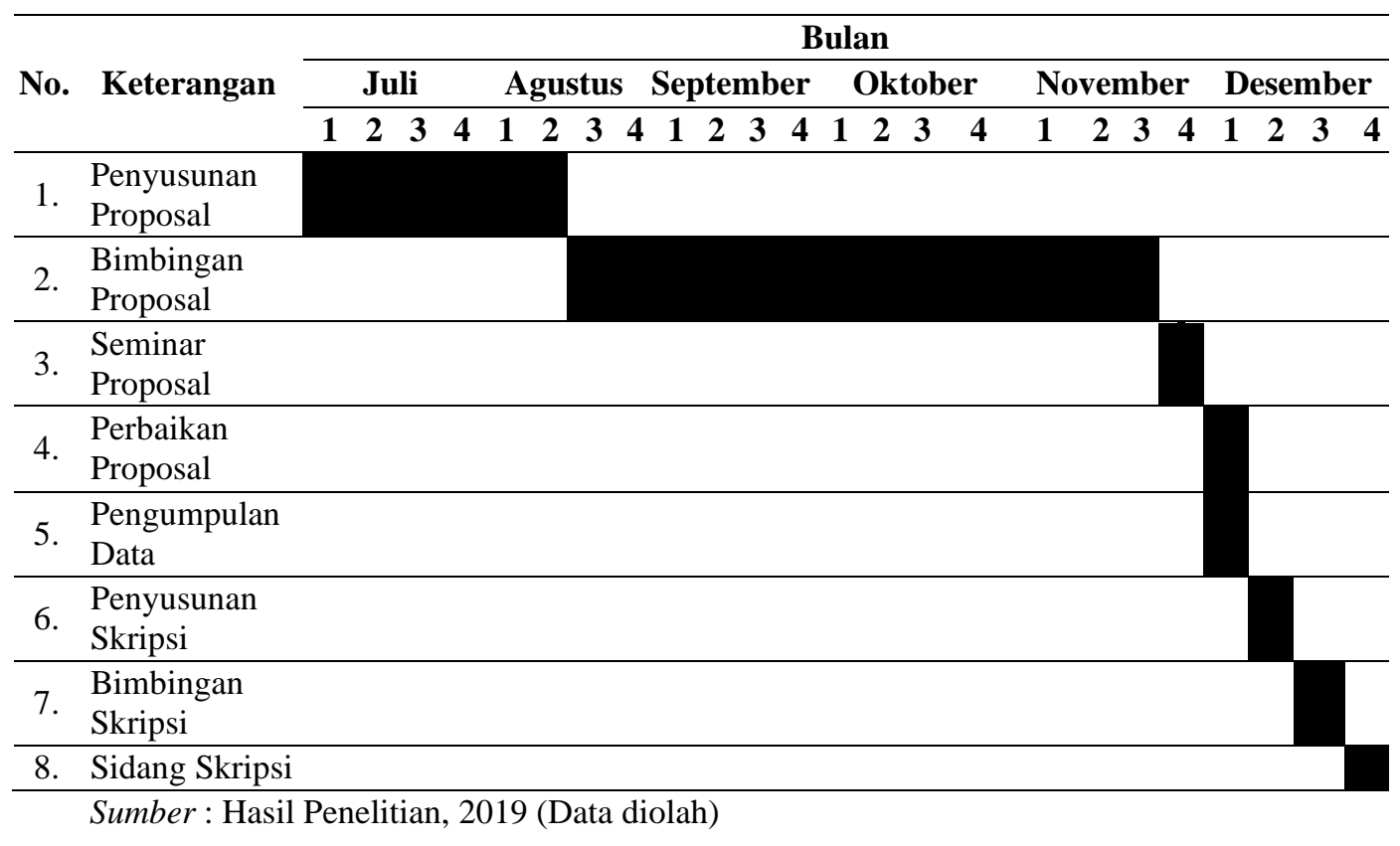

Menurut Torang (2016), uji validitas dimaksudkan untuk mengukur valid atau tidaknya suatu kuesioner. Kriteria sebagai berikut :

Jika $r_{\text {hitung }} \geq r_{\text {tabe }} l(0,361)$, dan nilai Sig. $<0,05$ maka pertanyaan dinyatakan valid Jika $r_{\text {hitung }}<r_{\text {tabel }}(0,361)$ dan nilai Sig. $<0,05$ maka pertanyaan dinyatakan tidak valid 
Tabel 6.

Definisi Operasional dan Pengukuran Variabel

\begin{tabular}{|c|c|c|c|}
\hline Variabel & Definisi & Indikator & $\begin{array}{c}\text { Skala } \\
\text { Pengukuraı }\end{array}$ \\
\hline $\begin{array}{l}\text { Kepuasan } \\
\text { Pelanggan } \\
\quad\left(\mathrm{X}_{1}\right)\end{array}$ & $\begin{array}{l}\text { Ukuran keberhasilan strategi pemasaran } \\
\text { perusahaan dalam memasarkan produk. } \\
\text { Pada dasarnya kepuasan pelanggan itu } \\
\text { suatu keadaan di mana kebutuhan dan } \\
\text { keinginan.Apabila produk sesuai atau } \\
\text { lebih baik dari yang diharapkan } \\
\text { pelanggan. }\end{array}$ & $\begin{array}{ll}\text { 1. } & \text { Kepuasan pelanggan } \\
& \text { secara keseluruhan } \\
\text { 2. } & \text { Dimensi kepuasan } \\
& \text { pelanggan } \\
\text { 3. Konfimasi harapan } \\
\text { 4. } \\
\text { 5. Kesediaan pembelian ulang } \\
\text { merekomendasikan }\end{array}$ & $\begin{array}{c}\text { Skala } \\
\text { Likert }\end{array}$ \\
\hline & Sumber : (Assauri, 2014) & Sumber : (Hasan, 2013) & \\
\hline $\begin{array}{c}\text { Kepercayaan } \\
\left(\mathrm{X}_{2}\right)\end{array}$ & $\begin{array}{l}\text { Kekuatan pengetahuan yang dimiliki } \\
\text { oleh konsumen dan semua kesimpulan } \\
\text { yang dibuat konsumen bahwa produk } \\
\text { mempunyai objek, atribut dan manfaat. }\end{array}$ & $\begin{array}{l}\text { 1. Sistem yang digunakan } \\
\text { 2. Reputasi } \\
\text { 3. risiko yang dipersepsikan } \\
\text { 4. Perceived web vendor } \\
\text { 5. Perceived web site } \\
\text { quality }\end{array}$ & $\begin{array}{l}\text { Skala } \\
\text { Likert }\end{array}$ \\
\hline & Sumber : (Sangadji \& Sopiah, 2013) & Sumber : (Priansa, 2017) & \\
\hline $\begin{array}{l}\text { Saluran } \\
\text { Distribusi } \\
\quad\left(\mathrm{X}_{3}\right)\end{array}$ & $\begin{array}{l}\text { Saluran distribusi adalah saluran atau } \\
\text { rute yang dipilih oleh perusahaan untuk } \\
\text { menyalurkan produk dari perusahaan ke } \\
\text { konsumen akhir atau pemakai industri }\end{array}$ & $\begin{array}{l}\text { 1. Physical distribution } \\
\text { 2. Pemasaran langsung } \\
\text { 3. Karakteristik } \\
\text { 4. Channel management } \\
\text { 5. Channel relation } \\
\text { Sumber: (Tjiptono, 2015) }\end{array}$ & $\begin{array}{l}\text { Skala } \\
\text { Likert }\end{array}$ \\
\hline $\begin{array}{l}\text { Keputusan } \\
\text { pembelian } \\
\text { (Y) }\end{array}$ & $\begin{array}{l}\text { Tahapan proses akhir dari serangkaian } \\
\text { tahapan proses yang terjadi pada } \\
\text { perilaku konsumen }\end{array}$ & $\begin{array}{l}\text { 1. Keputusan tentang jenis } \\
\text { produk. } \\
\text { 2. Keputusan tentang bentuk } \\
\text { produk. } \\
\text { 3. Keputusan tentang merek } \\
\text { 4. Keputusan tentang } \\
\text { penjualnya. } \\
\text { 5. Keputusan } \\
\text { Jumlah Produk tentang } \\
\text { Sumber: (Sudaryono, 2016) }\end{array}$ & $\begin{array}{l}\text { Skala } \\
\text { Likert }\end{array}$ \\
\hline
\end{tabular}

Sumber : Hasil Penelitian, 2019 (Data diolah)

Menurut Torang (2016), uji reliabilitas dimaksudkan untuk mengukur kuesioner yang merupkakan indikator dari variabel. Suatu konstruk atau variabel dikatakan reliabel jika memberikan nilai Cronbach alpha >0,60.

Menurut Surjaweni (2014) uji normalitas bertujuan untuk Mengetahui distribusi data dalam variabel yang akan digunakan dalam penelitian.

Untuk melihat data normalitas dapat melihat dengan grafik histogram dan dapat juga meliihat grafik nomal probability plot serta uji Kolmogorv-Sminorv (K$\mathrm{S})$. Normalitas data dapat dilihat dengan mengunakan uji normal Kolmogorov 
smirnov yaitu jika sig $>0,05$ maka berdistribusi normal dan jika sig $<0,05$ maka berdistribusi tidak normal

Menurut Ghozali (2016), uji multikolonieritas bertujuan untuk menguji apakah model regresi ditemukan adanya korelasi antar variabel bebas (Independen). Jika nila tolerance yang rendah sama dengan nilai VIF tinggi (karena $\mathrm{VIF}=1 /$ tolerance) dipakai untuk menunjukkan adanya multikolonieritas adalah nilai tolerance $\geq 0,10$ atau sama dengan nilai $\mathrm{VIF} \leq 10$.

Menurut Ghozali (2016), uji heteroskedastisitas bertujuan menguji apakah dalam model regresi terjadi ketidaksamaan variance dari residual satu pengamatan ke pengamatan yang lain. Ada beberapa cara untuk mendeteksi ada atau tidaknya heteroskedastisitas adalah sebagai berikut grafik Scatterplot dan uji Glejser. Kriteria uji Glejser yaitu: jika sig >0,05 maka tidak terjadi heteroskedastisitas dan jika sig < 0,05 maka terjadi heteroskedastisitas

Model penelitian yang digunakan dalam penelitian ini adalah analisis regresi linear berganda. Menurut Sunyoto (2014), analisis regresi berganda untuk mengetahui pengaruh dua atau lebih variabel bebas $(\mathrm{X} 1,2,3, \ldots, \mathrm{n})$ terhadap variabel terikat (Y). Rumusnya sebagai berikut :

$\mathrm{Y}=\mathrm{a}+\mathrm{b}_{1} \mathrm{X}_{1}+\mathrm{b}_{2} \mathrm{X}_{2}+\mathrm{e}$

$\begin{array}{lll}\text { Dimana: } & \mathrm{Y} & =\text { variabel keputusan pembelian } \\ & \mathrm{a} & =\text { konstanta } \\ \mathrm{b}_{1}, \mathrm{~b}_{2}, \mathrm{~b}_{3} & =\text { koefisien regresi } \\ \mathrm{X}_{1} & =\text { variabel Kepuasan Pelanggan } \\ \mathrm{X}_{2} & =\text { variabel Kepercayaan Pelanggan } \\ \mathrm{X}_{3} & =\text { variabel Saluran Distribusi } \\ \mathrm{e} & =\text { Standard error (tingkat kesalahan) } 5 \%\end{array}$

Koefisien Determinasi $\left(\mathrm{R}^{2}\right)$ digunakan untuk mengukur seberapa besar kontribusi variabel bebas (X) terhadap variabel terikat (Y). Menurut Kurniawan \& Yuniarto (2016)Adjusted $R$ Square dinotasikan dengan $R^{2}$ merupakan nilai koefisien determinasi terkoreksi yang menyesuaikan $R^{2}$ dengan cara membagi tiap sum of square dengan derajat bebasnya masing-masing. Dalam pemilihan model regresi terbaik, pengunaan $R^{2}$ jauh lebih baik jika dibandingkan dengan $R^{2}$. Hal ini dikarenakan koefisien ini mengambil jumlah parameter dalam model regresi kedalam perhitungan melalui derajat bebas.

Menurut Kurniawan \& Yuniarto (2016), uji simultan adalah uji semua variabel bebas secara keseluruhan dan bersamaan di dalam suatu model. Uji ini dilakukan untuk melihat apakah variabel independen secara keseluruhan berpengaruh signifikan terhadap variabel independen. Dalam penelitian ini nilai

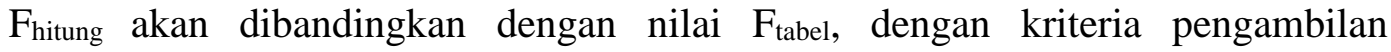
keputusannya adalah :

$\mathrm{H}_{0}: \mathrm{b}_{1}, \mathrm{~b}_{2}=0$, (Secara simultan kepuasan pelanggan, kepercayaan dan saluran distribusi tidak berpengaruh positif dan signfikan terhadap keputusan pembelian) $\mathrm{H}_{\mathrm{a}}: \mathrm{b}_{1}, \mathrm{~b}_{2} \neq 0$, (Secara simultan kepuasan pelanggan, kepercayaan dan saluran 
distribusi berpengaruh positif dan signfikan terhadap keputusan pembelian)

Dalam penelitian ini $F_{\text {hitung }}$ akan dibandingkan dengan $F_{\text {tabel }}$ pada tingkat signifikansi (a) $=5 \%$. Kriteria penelitian hipotesis pada uji $\mathrm{F}$ ini adalah:

$\mathrm{H}_{0}$ diterima apabila $\mathrm{F}_{\text {hitung }} \leq \mathrm{F}_{\text {tabel }}$ untuk tingkat signifikan $\alpha=5 \%$

$\mathrm{H}_{\mathrm{a}}$ diterima apabila $\mathrm{F}_{\text {hitung }}>\mathrm{F}_{\text {tabel }}$ untuk tingkat signifikan $\alpha=5 \%$

Menurut Kurniawan \& Yuniarto (2016) "Uji parsial digunakan untuk melihat pengaruh tiap-tiap variabel independen secara sendiri-sendiri terhadap variabel dependennya." Dengan ketentuan:

$\mathrm{H}_{0}: \mathrm{b}_{1}, \mathrm{~b}_{2}=0$, (Secara parsial kepuasan pelanggan, kepercayaan dan saluran distribusi tidak berpengaruh positif dan signfikan terhadap keputusan pembelian) $\mathrm{H}_{\mathrm{a}}: \mathrm{b}_{1}, \mathrm{~b}_{2} \neq 0$, (Secara parsial kepuasan pelanggan, kepercayaan dan saluran distribusi berpengaruh positif dan signfikan terhadap keputusan pembelian)

Dalam penelitian ini nilai $t_{\text {hitung }}$ akan dibandingkan dengan nilai $t_{\text {tabel, }}$ dengan kriteria pegambilan keputusannya adalah:

$\mathrm{H}_{0}$ diterima apabila $-\mathrm{t}_{\text {tabel }} \leq \mathrm{t}_{\text {hitung }} \leq \mathrm{t}_{\text {tabel }}$ ( dengan tingkat signifikan $\alpha=5 \%$ )

$\mathrm{H}_{\mathrm{a}}$ diterima apabila $\mathrm{t}_{\text {hitung }}<-\mathrm{t}_{\text {tabel }}$ atau $\mathrm{t}_{\text {hitung }}>\mathrm{t}_{\text {tabel }}$ (dengan tingkat signifikan $\alpha=5 \%)$

\section{HASIL DAN PEMBAHASAN}

PT Suminsurya Mesindolestari Medan adalah sebuah perusahaan yang bergerak dibidang penjualan baja. Sejak didirikan, kami telah berkomitmen memberikan pelayanan dan produk yang terbaik untuk pelanggan kami. Harga yang ditawarkan beraneka ragam maupun kualitas serta merek. Hal ini agar dapat memenuhi kebutuhan dan keinginan pelanggan sehingga perusahaan menyediakan variasi produk.

Adapun visi dari Baja Utama Wirasta Inti Medan yaitu menjadi salah satu perusahaan baja terlengkap dan terbaik di Sumatera Utara. Sedangkan misi dari . PT Suminsurya Mesindolestari Medan yaitu menjadi perusahaan yang tumbuh berkembang secara berkelanjutan didukung oleh sumber daya manusia yang kompeten, keselamatan dan kesehatan kerja dan menghemat energi melalui pengembangan teknologi dan sistem informasi yang handal, struktur keuangan yang kuat serta menjadikan kepuasan nilai kepuasan terbaik bagi pelanggan melalui harga terbaik, kompetitif, produk dan pelayanan berkwalitas serta garansi yang panjang terjamin mutu produk yg berkelas.

Tabel 7. dari 134 pelanggan yang menjadi responden pada penelitian ini yaitu responden yang berusia di bawah 20 tahun sebanyak 28 orang $(20,90 \%)$, responden yang berusia $20-30$ tahun yaitu sebanyak 36orang $(26,87 \%)$, responden yang berusia 31-40 tahun yaitu sebanyak 24orang $(17,91 \%)$ dan responden yang berusia > 40 tahun sebanyak 46 orang $(34,33 \%)$. Berdasarkan hasil tersebut mayoritas responden berusia di atas 40 tahun.

Berdasarkan Tabel 8. dari 134 pelanggan yang menjadi responden pada penelitian ini, sebanyak 91orang $(67,91 \%)$ berjenis kelamin laki-laki dan sebanyak 43 orang $(32,09 \%)$ berjenis kelamin perempuan. Hal ini berarti bahwa mayoritas responden berjenis kelamin laki-laki. 
Tabel 7.

Karakteristik Responden Berdasarkan Usia

\begin{tabular}{ccc}
\hline Usia & Jumlah Karyawan & Persentase \\
\hline$<20$ Tahun & 28 & 20.90 \\
20- 30 Tahun & 36 & 26.87 \\
31- 40 Tahun & 24 & 17.91 \\
$>$ 40 Tahun & 46 & 34.33 \\
Total & $\mathbf{1 3 4}$ & $\mathbf{1 0 0 \%}$ \\
\hline
\end{tabular}

Sumber : Hasil Penelitian, 2019 (Data diolah)

Tabel 8.

Karakteristik Responden Berdasarkan Jenis Kelamin

\begin{tabular}{ccc}
\hline Jenis Kelamin & Jumlah Karyawan & Persentase \\
\hline Laki-laki & 91 & 67.91 \\
Perempuan & 43 & 32.09 \\
Total & $\mathbf{1 3 4}$ & $\mathbf{1 0 0 \%}$ \\
\hline
\end{tabular}

Sumber : Hasil Penelitian, 2019 (Data diolah)

Tabel 9.

Karakteristik Responden Berdasarkan Lama Berlangganan

\begin{tabular}{ccc}
\hline Lama Berlangganan & Jumlah Karyawan & Persentase \\
\hline 1 tahun & 24 & 17.91 \\
2 Tahun & 41 & 30.60 \\
$>2$ tahun & 69 & 51.49 \\
Total & $\mathbf{1 3 4}$ & $\mathbf{1 0 0 \%}$ \\
\hline
\end{tabular}

Sumber : Hasil Penelitian, 2019 (Data diolah)

Berdasarkan Tabel 9. dari 134 pelanggan yang menjadi responden pada penelitian ini yaitu sebanyak 2 orang $(17,91 \%)$ yang mempunyai lama berlangganan 1 tahun, sebanyak 74 orang $(89,16 \%)$ yang mempunyai lama berlangganan 2 tahun dan sebanyak 5 orang $(6,02 \%)$ yang mempunyai lama berlangganan 2 tahun.

Ada dua cara untuk mendeteksi apakah residual berdistribusi normal atau tidak yaitu:

Uji grafik. Histogram adalah salah satu cara termudah untuk melihat normalitas residual adalah dengan melihat grafik histogram yang membandingkan antara data observasi dengan distribusi yang mendekati distribusi normal.

Grafik histogram pada Gambar 2. menunjukkan data riil membentuk garis kurva cenderung simetri (U) tidak melenceng ke kiri atau pun ke kanan maka dapat dikatakan data berdistribusi normal.

Probability Plot. Metode yang handal adalah dengan melihat normal probability plot yang membandingkan distribusi komulatif dari data sesungguhnya dengan distribusi kumulatif dari distribusi normal. Distribusi 
normal akan membentuk satu garis lurus diagonal, dan ploting data residual akan membandingkan dengan garis diagonal.

Tabel 10.

Descriptive Statistics

\begin{tabular}{cccccc}
\hline & N & Minimum & Maximum & Mean & Std. Deviation \\
\hline Kepuasanpelanggan & 134 & 10 & 50 & 32.82 & 13.592 \\
Kepercayaanpelanggan & 134 & 11 & 50 & 24.04 & 10.401 \\
Salurandistribusi & 134 & 10 & 50 & 27.07 & 12.606 \\
Keputusanpembelian & 134 & 10 & 50 & 24.30 & 11.878 \\
\hline Valid N (listwise) & 134 & & & & \\
\hline Sumber : Hasil Penelitian, 2019 (Data diolah) & &
\end{tabular}

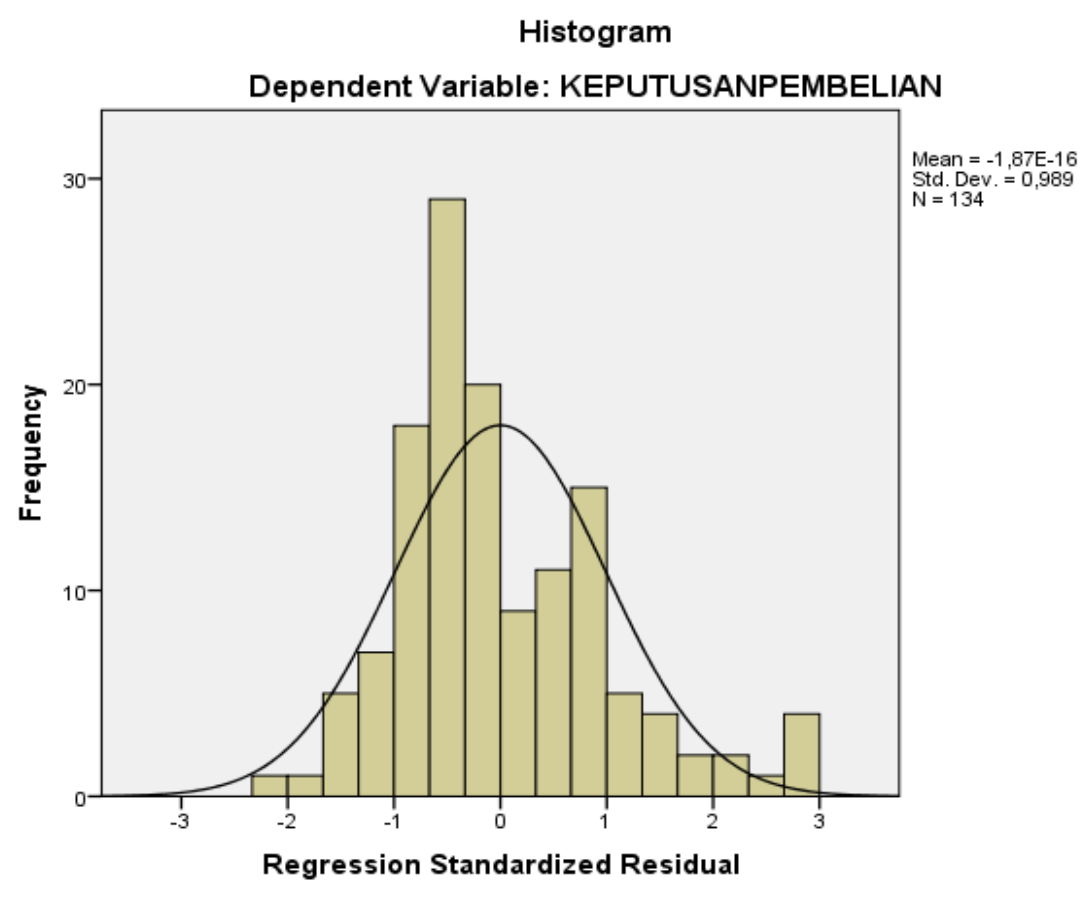

\section{Gambar 2. Uji Normalitas Histogram}

Sumber : Hasil Penelitian, 2019 (Data diolah)

Gambar 3. Grafik Normalitas P-P Plot terlihat data menyebar disekitar garis diagonal, penyebarannya sebagian besar mendekati garis diagonal. Hal ini berarti bahwa data berdistribusi normal.

Uji statistic. Uji normalitas dengan statistic dapat menggunakan uji statistic non-parametik Kolmogorov-smirnov (K-S), kriteria pengujiannya adalah :

Jika nilai signifikansi $>0,05$, maka data berdistribusi normal Jika nilai signifikansi $<0,05$, maka data tidak berdistribusi normal 


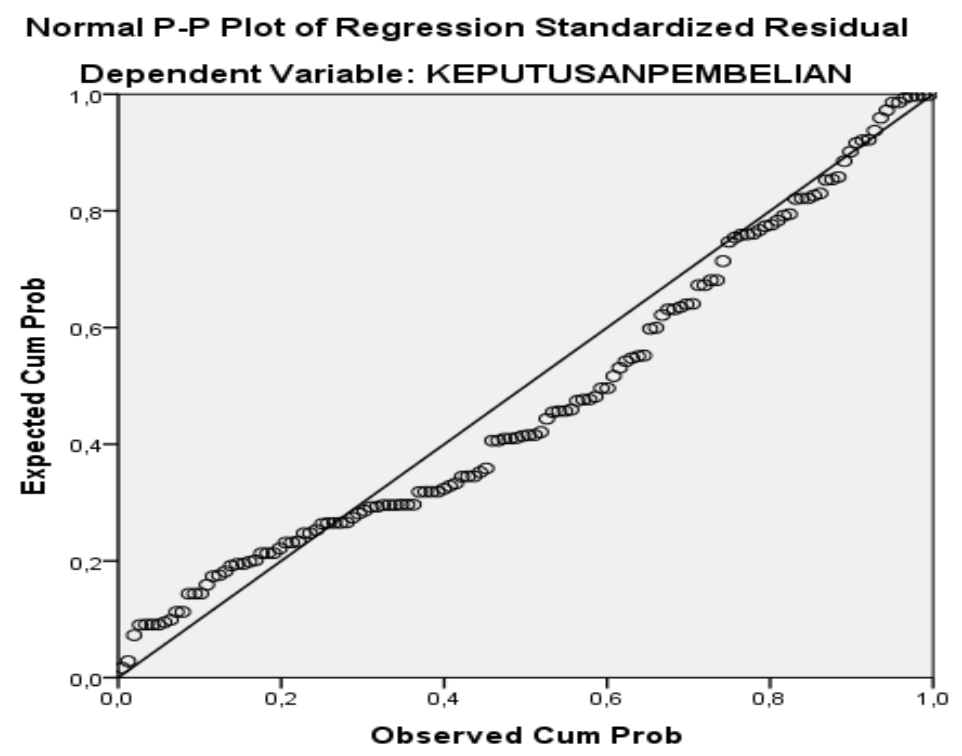

\section{Gambar 3. Uji Normalitas P-P Plot}

Sumber : Hasil Penelitian, 2019 (Data diolah)

Berikut ini adalah uji normalitas secara statistik menggunakan Kolmogorov Smirnov.

Tabel 11.

One-Sample Kolmogorov-Smirnov Test

\begin{tabular}{llr}
\hline & & $\begin{array}{c}\text { Unstandardized } \\
\text { Residual }\end{array}$ \\
\hline $\mathrm{N}$ & & 134 \\
Normal Parameters & Mean & $0 \mathrm{E}-7$ \\
& Std. Deviation & 9,90469950 \\
& Absolute &, 108 \\
Most Extreme Differences & Positive &, 108 \\
& Negative &,- 066 \\
Kolmogorov-Smirnov Z & & 1,256 \\
Asymp. Sig. (2-tailed) & &, 085 \\
\hline
\end{tabular}

a. Test distribution is Normal.

b. Calculated from data.

Sumber : Hasil Penelitian, 2019 (Data diolah)

Tabel 11. menunjukkan hasil uji normalitas dengan mengunakan pengujian Kolmogorov Smirnov menunjukkan nilai signifikan 0,085 > 0,05. Dengan demikian dari hasil uji Kolmogorov Smirnov menunjukkan data berdistribusi normal.

Tabel 12. menunjukkan bahwa nilai tolerance untuk variabel bebas yaitu kepuasan pelanggan sebesar 0,858>0,1, kepercayaan pelanggan sebesar 0,849> 0,1 dan saluran distribusi sebesar $0,866>0,1$, sedangkan nilai VIF untuk variabel 
bebas yaitu kepuasan pelanggan sebesar 1,165<10, kepercayaan pelanggan sebesar $1,178<10$ dan saluran distribusi sebesar $1,155<10$. Dengan demikian pada uji multikolinearitas tidak terjadi korelasi antar variabel bebas.

Tabel 12.

Uji Multikolinearitas

\begin{tabular}{|c|c|c|c|}
\hline \multirow{2}{*}{\multicolumn{2}{|c|}{ Model }} & \multicolumn{2}{|c|}{ Collinearity Statistics } \\
\hline & & Tolerance & VIF \\
\hline \multirow{4}{*}{1} & (Constant) & & \\
\hline & KEPUASANPELANGGAN & 858 & 1,165 \\
\hline & KEPERCAYAANPELANGGAN & 849 & 1,178 \\
\hline & SALURANDISTRIBUSI & 866 & 1,155 \\
\hline
\end{tabular}

Sumber : Hasil Penelitian, 2019 (Data diolah)

Uji heteroskedastisitas bertujuan menguji perbedaan variance residual suatu periode pengamatan ke periode pengamatan yang lain. Ada beberapa cara untuk mendeteksi ada atau tidaknya heteroskedastisitas:

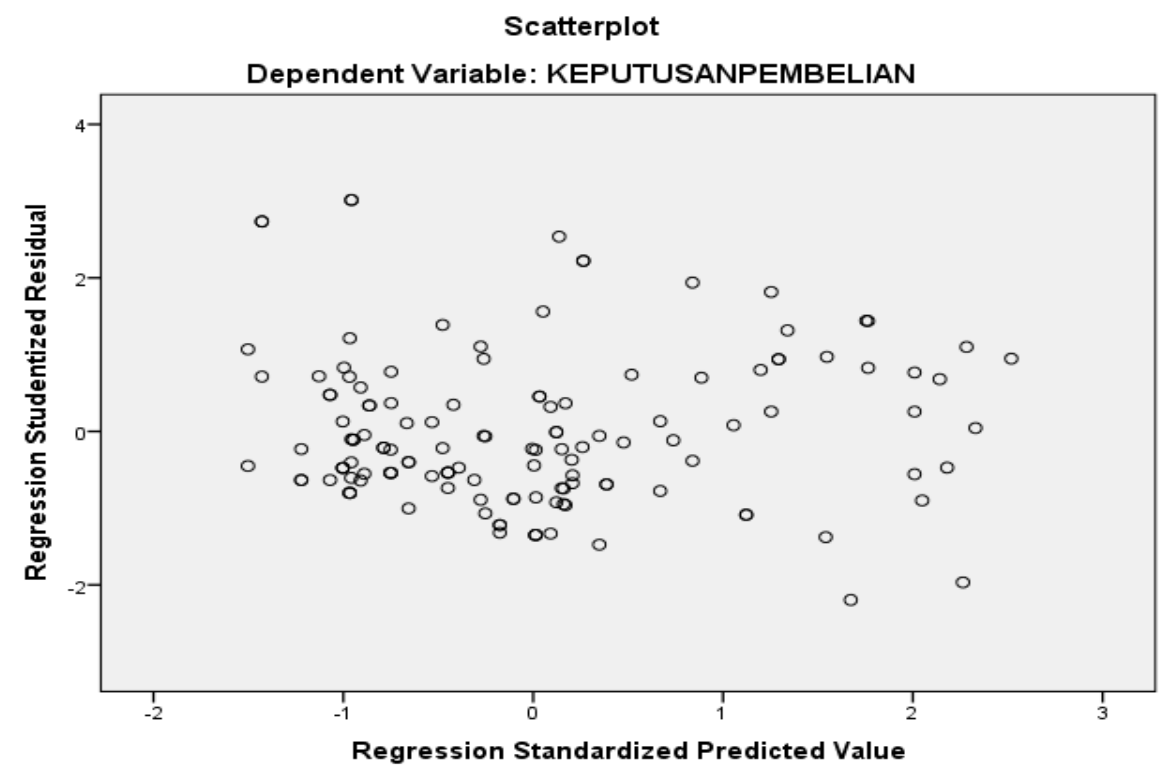

\section{Gambar 4. Uji Heteroskedastisitas}

Sumber : Hasil Penelitian, 2019 (Data diolah)

Dari grafik scatterplot terlihat bahwa titik-titik menyebar dengan pola yang tidak jelas baik diatas maupun dibawah angka nol (0) pada sumbu Y, tidak berkumpul di satu tempat, sehingga dari grafik scatterplot dapat disimpulkan bahwa tidak terjadi heteroskedastisitas pada model regresi.

Glejser yaitu ada atau tidaknya heteroskedastisitas dapat dilihat dari probabilitas signifikansinya, jika nilai signifikansinya di atas tingkat kepercayaan 5\% maka dapat disimpulkan tidak mengandung adanya heteroskedastisitas. 
Tabel 13.

Uji Glejser

\begin{tabular}{|c|c|c|c|c|c|c|}
\hline \multirow{2}{*}{\multicolumn{2}{|c|}{ Model }} & \multicolumn{2}{|c|}{$\begin{array}{l}\text { Unstandardized } \\
\text { Coefficients }\end{array}$} & \multirow{2}{*}{$\begin{array}{c}\begin{array}{c}\text { Standardized } \\
\text { Coefficients }\end{array} \\
\text { Beta }\end{array}$} & \multirow[b]{2}{*}{$\mathbf{t}$} & \multirow[b]{2}{*}{ Sig. } \\
\hline & & B & Std. Error & & & \\
\hline \multirow[t]{4}{*}{1} & (Constant) & 5.771 & 1.770 & & 3.260 & .001 \\
\hline & Kepuasanpelanggan & .025 & .043 & .055 & .585 & .559 \\
\hline & Kepercayaanpelanggan & .030 & .056 & .051 & .541 & .590 \\
\hline & Salurandistribusi & .015 & .046 & .030 & .324 & .746 \\
\hline
\end{tabular}

a. Dependent Variable: ABSUT

Sumber : Hasil Penelitian, 2019 (Data diolah)

Tabel 13. diatas menunjukkan nilai signifikan dari variabel bebas kepuasan pelanggan sebesar 0,559>0,05, variabel bebas kepercayaan pelanggan ebesar $0,590>0,05$ dan variabel bebas saluran distribusi sebesar 0,746 $>0,05$. Dengan demikian dari hasil uji Glejser dapat dikatakan tidak terjadi masalah heteroskedastisitas.

Rumus persamaan regresi linier berganda adalah sebagai berikut :

$$
\mathrm{Y}=\mathrm{a}+\mathrm{b}_{1} \mathrm{X}_{1}+\mathrm{b}_{2} \mathrm{X}_{2}+\mathrm{b}_{3} \mathrm{X}_{3}+\mathrm{e}
$$

Tabel 14.

Hasil Analisis Regresi Linear Berganda

Coefficients $^{\mathbf{a}}$

\begin{tabular}{llrrrrrr}
\hline Model & & \multicolumn{2}{c}{$\begin{array}{c}\text { Unstandardized } \\
\text { Coefficients }\end{array}$} & \multicolumn{2}{c}{$\begin{array}{c}\text { Standardized } \\
\text { Coefficients }\end{array}$} & & \\
\cline { 3 - 5 } & & \multicolumn{1}{c}{ B } & Std. Error & Beta & & t & \multicolumn{1}{c}{ Sig. } \\
\hline 1 & (Constant) & 3.759 & 2.859 & & 1.315 & .191 \\
& Kepuasanpelanggan & .246 & .069 & .282 & 3.569 & .001 \\
& Kepercayaanpelanggan & .309 & .091 & .271 & 3.411 & .001 \\
& Salurandistribusi & .186 & .074 & .197 & 2.508 & .013 \\
\hline
\end{tabular}

a. Dependent Variable: Keputusanpembelian

Sumber : Hasil Penelitian, 2019 (Data diolah)

$$
\mathrm{Y}=3,759+0,246 \text { Kepuasan Pelanggan + 0,309 Kepercayaan Pelanggan + 0,186 }
$$

Saluran Distribusi

Penjelasan regresi linier berganda diatas yaitu konstanta sebesar 3,759 menyatakan bahwa jika variabel bebas kepuasan pelanggan, kepercayaan pelanggan dan salurand istribusi tidak ada atau konstan maka variabel terikat keputusan pembelian pada sebesar 3,759 satuan. Koefisien regresi variabel bebas kepuasan pelanggan sebesar 0,249 dan bernilai positif, hal ini menyatakan bahwa setiap kenaikan variabel bebas kepuasan pelanggan 1 satuan akan meningkatkan variabel terikat keputusan pembelian sebesar 0,249 satuan dengan anggapan variabel lainnya tetap. Koefisien regresi variabel bebas kepercayaan pelanggan 
sebesar 0,309 dan bernilai positif, hal ini menyatakan bahwa setiap kenaikan variabel bebas kepercayaan pelanggan 1 satuan akan menyebabkan kenaikan variabel terikat keputusan pembelian pada sebesar 0,309 satuan dengan anggapan variabel lainnya tetap. Koefisien regresi variabel bebas saluran dsitribusi sebesar 0,186 dan bernilai positif, hal ini menyatakan bahwa setiap kenaikan variabel bebas saluran dsitribusi 1 satuan akan menyebabkan kenaikan variabel terikat keputusan pembelian pada sebesar 0,445 satuan dengan anggapan variabel lainnya tetap.

Adjusted $R$ Square dinotasikan dengan $R^{2}$ merupakan nilai koefisien determinasi terkoreksi yang menyesuaikan $R^{2}$ dengan cara membagi tiap sum of square dengan derajat bebasnya masing-masing.

Tabel 15.

Uji Koefisien Determinasi

\begin{tabular}{|c|c|c|c|c|}
\hline Model & $\mathbf{R}$ & R Square & Adjusted R Square & $\begin{array}{l}\text { Std. Error of the } \\
\text { Estimate } \\
\end{array}$ \\
\hline dimension0 1 & $.552^{\mathrm{a}}$ & .305 & .289 & 10.018 \\
\hline
\end{tabular}

Tabel 15. hasil uji koefisien determinasi diperoleh nilai Adjusted $R$ Square sebesar 0,289 hal ini berarti 28,9\% dari variasi variabel terikat yaitu keputusan pembelian yang dapat dijelaskan oleh variasi variabel bebas kepuasan pelanggan, kepercayaan pelanggan dan saluran distribusi sedangkan sisanya sebesar 73,6\% $(100 \%-26,4 \%)$ dijelaskan oleh variabel lain yang tidak diteliti pada penelitian ini, seperti persepsi, diferensiasi produk, strategi pemasaran sebagainya.

Pengujian statistik F pada dasarnya menunjukkan apakah semua variabel bebas yang dimasukkan dalam model mempunyai pengaruh secara simultan terhadap variabel dependen.

Tabel 16. derajat bebas $1\left(\mathrm{df}_{1}\right)=\mathrm{k}-1=4-1=3$, dan derajat bebas $2\left(\mathrm{df}_{2}\right)=$ $\mathrm{n}-\mathrm{k}=134-4=130$, dimana $\mathrm{n}=$ jumlah sampel, $\mathrm{k}=$ jumlah variabel, maka nilai $\mathrm{F}$ tabel pada taraf kepercayaan signifikansi 0,05 adalah 2,67. Hasil pengujian diperoleh nilai $\mathrm{F}_{\text {hitung }}\left(18,985>\mathrm{F}_{\text {tabel }}(2,67)\right.$ dan probabilitas signifikansi $0,000<$ 0,05, berarti bahwa secara simultan Kepuasan Pelanggan, Kepercayaan Pelanggan dan Saluran Distribusi berpengaruh positif dan signifikan terhadap Keputusan Pembelian Baja pada PT Suminsurya Mesindolestari Medan.

Uji t digunakan untuk mengetahui ada tidaknya hubungan atau pengaruh yang berarti (signifikan) antara variabel independen secara parsial terhadap variabel dependen.

Nilai tabel untuk probabilitas 0,05 pada derajat bebas $(\mathrm{df})=134-4=130$ adalah sebesar 1,978. Dengan demikian hasil dari pengujian hipotesis secara parsial dapat dijelaskan yaitu asil perhitungan pengujian hipotesis secara parsial diperoleh nilai $t_{\text {hitung }}>t_{\text {tabel }}$ atau 3,569 $>1,978$ dan signifikan yang diperoleh 0,001 $<0,05$, berarti bahwa secara parsial Kepuasan Pelanggan berpengaruh positif dan signifikan terhadap Keputusan Pembelian Baja pada PT Suminsurya 
Mesindolestari Medan. Hasil perhitungan pengujian hipotesis secara parsial diperoleh nilai $t_{\text {hitung }}>t_{\text {tabel }}$ atau 3,401 $>1,978$ dan signifikan yang diperoleh 0,001 $<0,05$, berarti bahwa secara parsial Kepercayaan Pelanggan berpengaruh positif dan signifikan terhadap Keputusan Pembelian Baja pada PT Suminsurya Mesindolestari Medan. Hasil perhitungan pengujian hipotesis secara parsial diperoleh nilai $t_{\text {hitung }}>t_{\text {tabel }}$ atau 2,508 $>1,978$ dan signifikan yang diperoleh 0,013 $<0,05$, berarti bahwa secara parsial Saluran Distribusi berpengaruh positif dan signifikan terhadap Keputusan Pembelian Baja pada PT Suminsurya Mesindolestari Medan.

Tabel 16.

Uji Simultan (Uji F)

ANOVA $^{b}$

\begin{tabular}{llrrrrr}
\hline Model & & Sum of Squares & df & Mean Square & F & Sig. \\
\hline 1 & Regression & 5716.351 & 3 & 1905.450 & 18.985 & $.000^{\mathrm{a}}$ \\
& Residual & 13047.709 & 130 & 100.367 & & \\
& Total & 18764.060 & 133 & & & \\
\hline
\end{tabular}

a. Predictors: (Constant), Salurandistribusi, Kepuasanpelanggan, Kepercayaanpelanggan

b. Dependent Variable: Keputusanpembelian

Sumber : Hasil Penelitian, 2019 (Data diolah)

Tabel 17.

Uji Parsial (Uji t)

Coefficients $^{\mathbf{a}}$

\begin{tabular}{|c|c|c|c|c|c|c|}
\hline \multirow{2}{*}{\multicolumn{2}{|c|}{ Model }} & \multicolumn{2}{|c|}{$\begin{array}{l}\text { Unstandardized } \\
\text { Coefficients }\end{array}$} & \multirow{2}{*}{$\begin{array}{c}\begin{array}{c}\text { Standardized } \\
\text { Coefficients }\end{array} \\
\text { Beta } \\
\end{array}$} & \multirow[b]{2}{*}{$\mathbf{t}$} & \multirow[b]{2}{*}{ Sig. } \\
\hline & & B & Std. Error & & & \\
\hline \multirow[t]{4}{*}{1} & (Constant) & 3.759 & 2.859 & & 1.315 & .191 \\
\hline & Kepuasanpelanggan & .246 & .069 & .282 & 3.569 & .001 \\
\hline & Kepercayaanpelanggan & .309 & .091 & .271 & 3.411 & .001 \\
\hline & Salurandistribusi & .186 & .074 & .197 & 2.508 & .013 \\
\hline
\end{tabular}

a. Dependent Variable: Keputusanpembelian

Sumber : Hasil Penelitian, 2019 (Data diolah)

Hasil perhitungan pengujian hipotesis secara parsial diperoleh nilai $t_{\text {hitung }}>$ $t_{\text {tabel }}$ atau 3,569 > 1,978 dan signifikan yang diperoleh 0,001 $<0,05$, berarti bahwa secara parsial Kepuasan Pelanggan berpengaruh positif dan signifikan terhadap Keputusan Pembelian Baja pada PT Suminsurya Mesindolestari Medan.

Hasil penelitian ini juga sejalan dengan teori menurut (Malau, 2017), Tingkah laku tentang keputusan pembelian individu, kelompok atau organisasi dan proses merek digunakan untuk memilih, produk dengan cara pencapaian kepuasan pelanggan dalam mengkonsumsi suatu produk.

Kepuasan pelanggan berperan penting dalam upaya peningkatkan keputusan pembelian. Persaingan yang semakin ketat, dimana banyak produsen yang terlibat dalam pemenuhan kebutuhan dan keinginan konsumen, menyebabkan setiap 
perusahaan harus menempatkan orientasi pada kepuasan pelanggan sebagaitukuan utama. Hal ini tercermin dari semakin banyaknya perusahaan yang menyertakan komitmen terhadap kepuasan pelanggan PT. Suminsurya Mesindolestari Medan dalam pernyataan iklan maupun public relations release. Kepuasan pelanggan berperan penting dalam keputusan pembelian yanag dilakukan oleh pelanggan. Pada perusahaan ini terjadinya peningkatan keluhan pelanggan kepada perusahaan. Banyaknya keluhan ini berupa mengenai pelayanan yang belum memuaskan yaitu dalam kecepatan dalam menagani keluhan dari para pelangga, kepuasan terhadap harga yang sering fluktuasi dan sebagainya. Tingginya keluhan pelanggan kepada perusahaan hal ini menunjukkan betapa tidak berkualitasnya pelayanan yang diberikan yang menciptakan kekecewaaan pelanggan yang tidak singgap dalam memberikan pelayanan dan ketidaksesuaian pesanan. Hal ini berdampak pada keputusan pembelian yang mengalami penurunan terbukti dari banyaknya pelanggan yang lebih memilih membeli pada perusahaan lainnya yang sejenis yang lebih memuaskan.

Hasil perhitungan pengujian hipotesis secara parsial diperoleh nilai $t_{\text {hitung }}>$ $\mathrm{t}_{\text {tabel }}$ atau 3,401 $>1,978$ dan signifikan yang diperoleh $0,001<0,05$, berarti bahwa secara parsial Kepercayaan Pelanggan berpengaruh positif dan signifikan terhadap Keputusan Pembelian Baja pada PT Suminsurya Mesindolestari Medan.

Hasil penelitian ini juga sejalan dengan teori menurut (Limakrisna \& Susilo, 2012), Kepercayaan merupakan alat yang sangat penting dalam pemasaran yang menjadi salah satu faktor yang dapat mempengaruhi keputusan pembelian pelanggan dalam suatu produk di dalam sektor public.

Banyaknya pelanggan yang kurang mempercayai staf perusahaan PT Suminsurya Mesindolestari Medan. Hal ini menyebabkan jumlah pelanggan yang mengalami penurunan. Penyebab ketidakpercayaan dari pelanggan PT Suminsurya Mesindolestari Medan adalah seringnya infromasi yang diberikan tidak reliabel baik dari segi informasi produk maupun harga produk baja. Hal ini seringnya menimbulkan kekecewaaan yang berdampak banyak pelanggan PT Suminsurya Mesindolestari Medan berahli ke perusahaan .Terjadinya penurunan pelanggan pada perusahaan yang diakibatkan ketidakreliabel para staf perusahaan. Besarnya kepercayaan konsumen terhadap suatu perusahaan dan produk atau jasa yang dijual berkaitan dengan besarnya kepercayaan mereka terhadap sistem pembayaran yang digunakan perusahaan yang sungguh mengecewakan para pelanggan serta reputasi yang serign tidak tanggap dan reliabel dalam melayani menjadi faktor pemicu ketidakpercayaan pelanggan.

Hasil perhitungan pengujian hipotesis secara parsial diperoleh nilai $t_{\text {hitung }}>$ $\mathrm{t}_{\text {tabel }}$ atau 2,508 $>1,978$ dan signifikan yang diperoleh $0,013<0,05$, berarti bahwa secara parsial Saluran Distribusi berpengaruh positif dan signifikan terhadap Keputusan Pembelian Baja pada PT Suminsurya Mesindolestari Medan.

Hasil penelitian ini sama dengan hasil penelitian Asir (2012) bahwa Saluran Distribusi berpengaruh positif dan signifikan terhadap Keputusan Pembelian.

Hasil penelitian ini juga sejalan dengan teori menurut Yuniarti (2015:240), kepercayaan konsumen tidak terbentuk dalam waktu singkat, tetapi melalui proses belajar dan bersasarkan hasil pengalaman konsumen dari pembelian konsisten 
sepanjang waktu. Apabila sesuai dengan harapan, proses pembelian ini terus berulang, hal ini dikatakan bahwa telah timbul kepercayaan konsumen

Saluran distribusi berperang aktif dalam peningkatan maupun penurunan keputusan pembelian. Pada perusahaan ini saluran distribusi yang belum efektif menimbulkan keluhan berupa seringnya produk baja yang di pesan tidak sesuai jadwal pengantaran yang telah disepaakati, jenis dan ukuran yang di pesan sering mengalami kesalahan, beberapa produk baja seringnya kosong sehingga belum dapat memenuhi keinginan pelanggan dengan cepat dan tepat. Menunjukkan bahwa tingginya keluhan mengenai kurang efektif saluran distribusi yang dimiliki oleh perusahaan sehingga menimbulkan kekecewaan pelanggan. Dimana keterangan keluhan berupakan pengiriman tidak tepat waktu, ketidaksesuaic jumlah produk dan jenis yang diinginkan pelanggan tidak sesuai dengan pesanán serta persediaan yang kurang banyak sehingga mengecewakan pelanggan. Hal ini diakibatkan cakupan pasar yang cukup jauh dan komunikasi yang kurang dilakukan oleh pihak perusahaan kepada pelanggan.

\section{SIMPULAN}

Simpulan dari hasil penelitian ini yaitu hipotesis secara parsial diperoleh nilai $t_{\text {hitung }}>\mathrm{t}_{\text {tabel }}$ atau 3,569 $>1,978$ dan signifikan yang diperoleh 0,001 $<0,05$, berarti bahwa secara parsial Kepuasan Pelanggan berpengaruh positif dan signifikan terhadap Keputusan Pembelian Baja pada PT Suminsurya Mesindolestari Medan. Hipotesis secara parsial diperoleh nilai $t_{\text {hitung }}>t_{\text {tabel }}$ atau 3,401 > 1,978 dan signifikan yang diperoleh $0,001<0,05$, berarti bahwa secara parsial Kepercayaan Pelanggan berpengaruh positif dan signifikan terhadap Keputusan Pembelian Baja pada PT Suminsurya Mesindolestari Medan. Hipotesis secara parsial diperoleh nilai $t_{\text {hitung }}>t_{\text {tabel }}$ atau 2,508 $>1,978$ dan signifikan yang diperoleh $0,013<0,05$, berarti bahwa secara parsial Saluran Distribusi berpengaruh positif dan signifikan terhadap Keputusan Pembelian Baja pada PT Suminsurya Mesindolestari Medan. Hasil pengujian diperoleh nilai $\mathrm{F}$ hitung $(18,985$ $>\mathrm{F}$ tabel $(2,67)$ dan probabilitas signifikansi $0,000<0,05$, berarti bahwa secara simultan Kepuasan Pelanggan, Kepercayaan Pelanggan dan Saluran Distribusi berpengaruh positif dan signifikan terhadap Keputusan Pembelian Baja pada PT Suminsurya Mesindolestari Medan.

Saran-saran yang berguna bagi penelitian ini yaitu agi Perusahaan, peningkatan ketiga variabel tersebut baik secara parsial maupun bersama-sama dapat meningkatkan keptuusan pembelian secara maksimal. Maka disarankan agar perusahaan dapat meningkatkan dan memperbaiki kedua variabel tersebut di dalam perusahaan. Bagi peneliti selanjutnya, disarankan untuk menambah variabel lain di luar dari variabel yang diteliti oleh peneliti. Bagi peneliti, diharapkan dapat mempraktekkan hasil penelitian di perusahaan tempat peneliti bekerja dan memperoleh gelar S1 Manajemen. 


\section{REFERENSI}

Arikunto, S. (2014). Prosedur Penelitian Suatu Pendekatan Praktik. Jakarta: Rineka Cipta.

Assauri, S. (2014). Manajemen Pemasaran. Jakarta : Rajawali Pers.

Ghozali, I. (2016). Aplikasi Analisis Multivariate dengan Program IBM SPSS 23. (Edisi 8). Semarang: Badan Penerbit Universitas Diponegoro.

Hasan, A. (2013). Marketing dan Kasus-kasus Pilihan. Cetakan Kesatu. Yogyakarta: CAPS (Center for Academic Publishing Service).

Herlambang, S., \& Marwoto, B. H. (2014). . Manajemen Kesekretariatan. Yogyakarta: Gosyen Publishing.

Kotler dan Keller. (2017). Manajemen Pemasaran, Edisi 12, Jilid 1, PT.Indeks,. Jakarta. In $e$-Jurnal Riset Manajemen.

Kotler, N. G., Kotler, P., \& Kotler, and W. I. (2016). Chapter 3: Moving to strategic planning. In Museum Marketing and Strategy.

Kotler, P., \& Keller, K. L. (2009). Manajemen pemasaran Jilid 1. In Jakarta.

Kurniawan, R., \& Yuniarto, B. (2016). Analisis Regresi Dasar dan Penerapan dengan $R$. Jakarta : Prenadamedia Group.

Limakrisna, N., \& Susilo, W. H. (2012). Manajemen Pemasaran Teori Dan Aplikasi Dalam Bisnis. In MANAJEMEN PEMASARAN Teori dan Aplikasi Dalam Bisnis.

Malau, H. (2017). Manajemen Pemasaran. CV Alfabeta. Bandung.

Nitisusastro, M. (2012). Perilaku Konsumen Dalam Perspektif Kewirausahaan. Alfabeta, Bandung.

Peter, P. J., \& Olson, J. C. (2013). Perilaku Konsumen dan Strategi Pemasaran. In Salemba Empat.

Priansa, D. J. (2017). Perilaku Konsumen. Penerbit Alfabeta, Bandung.

Sangadji, E. M., \& Sopiah. (2013). Perilaku Konsumen: Pendekatan Praktis Disertai Himpunan Jurnal Penelitian. Penerbit Salemba, 342.

Schiffman, L., \& Kanuk, L. L. (2007). Perilaku Konsumen Edisi Kedua. In PT. Indeks Gramedia.

Sudaryono. (2016). Manajemen Pemasaran Teori \& Implementasi. Yogyakarta: CV. Andi Offset.

Sugiyono. (2017). Metode Penelitian Bisnis (Pendekatan Kuantitatif, Kualitatif, Kombinasi dan R\&DSugiyono. (2017). Metode Penelitian Bisnis (Pendekatan Kuantitatif, Kualitatif, Kombinasi dan R\&D). In Metodelogi Penelitian.). In Metodelogi Penelitian. 
Demak Claudia Yosephine Simanjuntak, Pengaruh Kepuasan Pelanggan...

Sunyoto, D. (2014). Perilaku Konsumen. Cetakan Kesatu. Yogyakarta : Center for Academic Publishing Service.

Surjaweni, W. V. (2014). SPSS Untuk Penelitian. Yogyakarta: Pustaka Baru Press.

Swastha, B., \& Handoko, T. H. (2000). Manajemen pemasaran: Analisa perilaku konsumen. BPFE, Yogyakarta.

Tjiptono, F. (2015). Strategi Pemasaran, Edisi 4. Andi, Yogyakarta.

Torang, S. (2016). Organisasi dan Manajemen (Perilaku Struktur, Budyaa dan Perubahan Organisasi. Bandung: Alfabeta. 